\title{
Human papillomavirus-16 presence and physical status in lung carcinomas from Asia
}

\author{
Francisco Aguayo 1,6 Muhammad Anwar ${ }^{2}$, Chihaya Koriyama², Andres Castillo², Quanfu Sun ${ }^{3}$, Jacob Morewaya ${ }^{4}$, \\ Yoshito Eizuru ${ }^{5}$, Suminori Akiba ${ }^{2^{*}}$
}

\begin{abstract}
Background: Although human papillomavirus (HPV) genome has been detected in lung cancer, its prevalence is highly variable around the world. Higher frequencies have been reported in far-east Asian countries, when compared with European countries. The present study analysed the HPV-16 presence in 60 lung carcinomas from the Asian countries China, Pakistan and Papua New Guinea.

Results: HPV-16 was present in 8/59 (13\%) samples. According to histological type, HPV-16 was detected in 8/18 (44\%) squamous cell carcinomas (SQCs), which were mainly from Pakistan; 0/38 (0\%) adenocarcinomas (ACs), which were mainly from China; and in 0/4 (0\%) small cell carcinomas (SCLCS). The observed histological difference was statistically significant $(p<0.001)$. HPV-16 viral load was also determined using real-time polymerase chain reaction (qRT-PCR); it ranged between 411 to 2345 copies/100 ng of genomic DNA. HPV-16 genome was found integrated into the host genome in every HPV-16 positive carcinoma.

Conclusion: These results support the notion that HPV-16 infection is highly associated with SQCs in Pakistan. Our results show a frequent HPV-16 integration in SQCs, although the low viral load casts doubt respect a direct etiological role of HPV in lung carcinomas from Asia. Additional HPV-16 characterization is necessary to establish a direct or indirect etiological role of HPV in this malignancy.
\end{abstract}

\section{Background}

Human papillomaviruses (HPVs) are epitheliotropic double-stranded DNA viruses that belong to the papillomaviridae family. Epidemiological, clinical and basic research has allowed to conclude that HPV infection is the necessary cause of cervix uterine cancer [1]. In addition, HPV has been associated with other extra-genital malignancies such as cancers of the head and neck, esophageal, skin and lung [2]. The prevalence of HPV in lung cancer is highly variable around the world. A meta-analysis made by Srinivasan reported that HPV frequency in lung carcinomas ranged between 0 to $78.3 \%$ worldwide. Relatively high frequencies are found in Far East Asian countries when compared with European countries [3]. In addition, HPV is suspected to predispose to particular histological subtypes of lung cancer. A study in Okinawa, southern islands

\footnotetext{
* Correspondence: akiba@m.kufm.kagoshima-u.ac.jp

${ }^{2}$ Department of Epidemiology and Preventive Medicine, Kagoshima University Graduate School of Medical and Dental Sciences, 8-35-1 Sakuragaoka, Kagoshima, 890-8544, Japan

Full list of author information is available at the end of the article
}

of Japan, found that HPV was detected in $79 \%$ of the cases, particularly in the well-differentiated SQCs. However, the proportion of HPV-positive lung carcinomas in Okinawa decreased in the $1990 \mathrm{~s}$, in parallel with the falling incidence of well differentiated SQCs, and was only $24 \%$ in the late $1990 \mathrm{~s}$ [4]. Relatively high HPV prevalence rates in SQCs were found in our study in Chile [5] and studies in central China [6]. However, the association of HPV to lung SQC is not always observed. For example, an Iranian study showed no evident association to any histological types [7]: HPV was found in $25 \%$ of SQCs, $21 \%$ of ACs, $33 \%$ of large cell lung carcinomas and $29 \%$ of small cell lung carcinomas (SCLCs). In Europe, one study analysed 218 frozen specimens of lung carcinomas from France, using Roche line blot assay, and found only four HPV positive samples, one poorly differentiated SQC and three large cell carcinomas [8]. A Korean study did not show any histological association of HPV, either [9]. On the other hand, studies conducted in Taiwan and in Kagoshima, Japan, showed a high prevalence of HPV in ACs. In a Taiwanese study, HPV-16 and HPV-18 were 
positive in $43 \%$ and $49 \%$ of ACs, respectively, but only in $24 \%$ and $29 \%$ of SQCs, respectively [10]. Interestingly, a recent study in Kagoshima, Japan, examined 20 additional ACs treated with gefitinib, a tyrosine kinase inhibitor specific for epidermal growth factor receptor (EGFR), and detected high-risk HPV genomes in 75\% (7/8) of ACs with complete or partial response to gefitinib but not in the remaining 12, which did not respond to gefitinib [11]. Note that non-smoking women with East Asian ethnicity is a predictive factor of gefitinib responsive ACs [12].

In general, high risk-HPVs are frequently integrated in cervical cancer, and low risk-HPVs are frequently found to be episomal [13]. Moreover, it has been reported that HPV integration is more frequently found in high-grade lesions (invasive carcinoma) when compared with low grade lesions [14]. The HPV integration frequently disrupts E2 ORF causing E6 and E7 overexpression because E2 protein functions as a repressor of $\mathrm{p} 97$ promoter in HPV-16. The E6 and E7 overexpression induce p53 and $\mathrm{pRb}$ loss, respectively [15]. In cervical carcinogenesis, deregulated expression of these two viral oncogenes in basal cells, mostly by HPV integration, is considered to be a critical event for disease progression [16].

Epidemiological evidence suggests that pathways involved in HPV-induced oncogenesis may be influenced by ethnic factors and anatomical location as well as exposures to risk factors such as smoking and alcohol [17]. Thus, it is of interest to study the prevalence and function of HPV-16 in lung carcinomas from countries with different lifestyles. In the present study we examined lung cancer specimens from Asian countries such as China, Pakistan and Papua New Guinea. Studies on HPV prevalence in lung cancer in Pakistan or Papua New Guinea have not been reported to date. In addition, in order to characterize the role of HPV in this tumour, we determined the physical status (episomal/ integrated) and viral load in HPV-16 positive cases.

\section{Results}

The present study analysed the HPV-16 presence in lung carcinomas from Pakistan, China and Papua New Guinea. The clinicopathological features of analysed specimens are shown in Table 1 . No statistically significant differences were observed between analysed histological types and age, gender or differentiation status $(P=$ $0.295,0.133$ and 0.179 , respectively). All ACs analysed in this study were obtained from China and all SQCs were obtained from Pakistan and Papua New Guinea. Thus, in this study there was a statistically significant difference between analysed histological type of lung cancer and countries involved $(P<0.05)$.

We successfully purified DNA in all the analysed specimens. The DNA was highly pure (Absorbance 260/280 = $1,8)$ and its concentration was ranged between 50 to
Table 1 Clinicopathological features of lung carcinomas from China, Pakistan and Papua New Guinea

\begin{tabular}{llccccc}
\hline & & Al* $^{*}$ & \multicolumn{3}{c}{ histological types } & p-value \\
& & & ACs & SQCs & SCLCs & \\
\hline Age & -64 & 38 & $23(61)$ & $11(29)$ & $4(11)$ & \\
& $65+$ & 18 & $14(78)$ & $4(22)$ & $0(0)$ & \\
Gender & & & & & & 0.133 \\
& Male & 43 & $24(56)$ & $16(37)$ & $3(7)$ & \\
Differentiation & Female & 17 & $14(82)$ & $2(12)$ & $1(6)$ & \\
& & & & & & 0.179 \\
& poor & 19 & $11(58)$ & $8(42)$ & $0(0)$ & \\
& moderate & 26 & $17(65)$ & $9(35)$ & $0(0)$ & \\
& well & 11 & $10(91)$ & $1(9)$ & $0(0)$ & \\
& & & & & & $<0.005$ \\
& Pakistan & 21 & $4(19)$ & $13(62)$ & $4(19)$ & \\
& China & 31 & $31(100)$ & $0(0)$ & $0(0)$ & \\
& PNG & 8 & $3(38)$ & $5(62)$ & $0(0)$ & \\
\hline
\end{tabular}

* Ages and tumor differentiation was not available in four cases PNG: Papua New Guinea.

$100 \mathrm{ng} / \mu \mathrm{L}$. In addition, to check the DNA fragmentation and presence of amplifiable DNA for PCR, we successfully amplified a 110 betaglobin DNA fragment in all of specimens. PCR with GP5+/6+ primers revealed that $8 / 60$ (13\%) cases were HPV positive. In order to determine the HPV genotype, we used PCR for amplification of a HPV-16 E6 specific DNA fragment. All the cases that were HPV GP5+/6+ positive were typed as HPV-16. We confirmed these results using PCR for amplification of another 65 bp DNA fragment of HPV-16 E6 [18] (Figure 1A y 1B). No other HPV genotype was found in this study. The HPV-16 genotype was present in SQCs (8/18) but not in ACs or SCLCs (Table 2) and this difference among histological types was statistically significant $(P<0.001)$. Gender, age or tumour differentiation was not significantly associated with HPV-16 presence $(P=$ $0.091,0.669$ and 0.131 , respectively). In addition, we used real-time PCR to determine viral load and physical status of HPV. All the HPV-16 positive specimens were

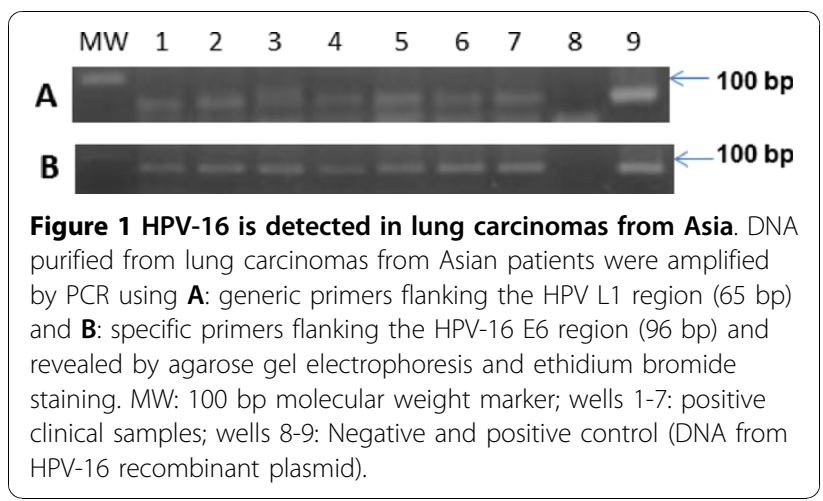


Table 2 Clinicopathological features of HPV-16-positive lung carcinomas

\begin{tabular}{|c|c|c|c|c|c|}
\hline & & $\begin{array}{c}\text { All } \\
N(\%)\end{array}$ & $\begin{array}{l}\text { HPV16 positive } \\
\mathrm{N}(\%)\end{array}$ & $\begin{array}{c}\text { HPV16 negative } \\
\mathrm{N}(\%)\end{array}$ & $\mathrm{p}$-value \\
\hline \multirow[t]{3}{*}{ Age } & & & & & 0.669 \\
\hline & $<65$ years & 38 & $4(11)$ & $34(89)$ & \\
\hline & $>65$ years & 18 & $3(17)$ & $15(83)$ & \\
\hline \multirow[t]{3}{*}{ Gender } & & & & & 0.091 \\
\hline & Male & 43 & $8(19)$ & $35(81)$ & \\
\hline & Female & 17 & $0(0)$ & $17(100)$ & \\
\hline \multirow[t]{4}{*}{ Histology } & & & & & $<0.001$ \\
\hline & $A C$ & 38 & $0(0)$ & $38(100)$ & \\
\hline & SQC & 18 & $8(44)$ & $10(56)$ & \\
\hline & SCLC & 4 & $0(0)$ & $4(100)$ & \\
\hline \multirow[t]{4}{*}{ Differentiation } & & & & & 0.131 \\
\hline & Poor & 19 & $5(26)$ & $14(74)$ & \\
\hline & Moderate & 26 & $3(12)$ & $23(88)$ & \\
\hline & Well & 11 & $0(0)$ & $11(100)$ & \\
\hline \multirow[t]{4}{*}{ Country } & & & & & 0.001 \\
\hline & Pakistan & 21 & 7 (33) & $14(67)$ & \\
\hline & China & 31 & $0(0)$ & $31(100)$ & \\
\hline & PNG & 8 & $1(13)$ & 9 (87) & \\
\hline
\end{tabular}

successfully amplified for an 81 bp fragment of E6 gene but only 3 specimens were successfully amplified for an 82 bp fragment of E2 gene (Figures $2 \mathrm{~A}$ and $2 \mathrm{C}$ ). The amplified fragments were characterized by melting analysis that showed a specific curve with a Tm (melting temperature) of $77.6^{\circ} \mathrm{C}$ for the $\mathrm{E} 6$ fragment and $81.7^{\circ} \mathrm{C}$ for the $\mathrm{E} 2$ fragment. One specimen positive for $\mathrm{E} 2$ gene showed a $\mathrm{Tm}$ that was higher $0.5^{\circ} \mathrm{C}$ approximately compared with the other two specimens (Figures 2B and 2D). The specific presence of amplification products was checked by agarose gel electrophoresis and ethidium bromide staining in all the samples (data not shown). We found that HPV-16 viral load ranged between 411 to 42141 copies/100 ng of genomic DNA, and the HPV-16 genomes were absolutely integrated in 5/8 (63\%) positive lung carcinomas. In 3/8 (37\%) carcinomas, episomal and integrated HPV genome was present simultaneously (Table 3). No relationship was observed between HPV-16 viral load and integration status.

\section{Discussion}

In this study HPV-16 was found in $13 \%$ of the lung carcinomas. This finding is consistent with other reports where HPV-16 has been the most common HPV genotype detected in lung cancer [3]. HPV-16 genome was detected only in SQCs (44\%) but not in the other histological types (Table 2). These results support the notion that SQCs are more strongly associated with high-risk HPV in the areas other than far-east Asia. On the other hand, the absence of HPV genomes in ACs present a contrast to what was found by studies in Taiwan and
Japan, where HPV-16 genome was more frequently found in ACs than in SQCs [10,11]. Since ACs responsive to gefitinib tend be located in the lung periphery, tumor location may be an explanation for those discrepant results. Note that ACs surgically resected in the mainland China may be more centrally located.

Epidemiological evidence suggests that pathways involved in HPV-mediated oncogenesis are influenced by ethnic factors and anatomic location as well as exposures to risk factors such as smoking or alcohol [17]. The most important risk factor of lung cancer is smoking. However, no studies reported an evident interactive effect between HPV infection and tobacco smoking on lung cancer risk. On the other hand, a Taiwanese study that showed a high prevalence of high-risk HPV in nonsmoking women [10]. Although 14 ACs in our study were mainly from Chinese women, who tend to be nonsmokers, we did not have information about smoking habit in these patients. Therefore, we could not examine the possibility of high HPV prevalence in lung ACs among non-smoking women. Another risk among nonsmoking Asian women is long exposure to kitchen fumes [19], which is however, not a common exposure in Japan. Recently, a Taiwanese study reported an increased lung cancer risk in relation to mosquito coil use [20], which is commonly used in Asian countries, including Japan. Other possible environmental risk factors may be heavy metals: A Taiwanese study reported the accumulation of chromium and nickels in lung carcinomas [21]. It should also be noted that arsenic poisoning from artesian well water cause black-foot 


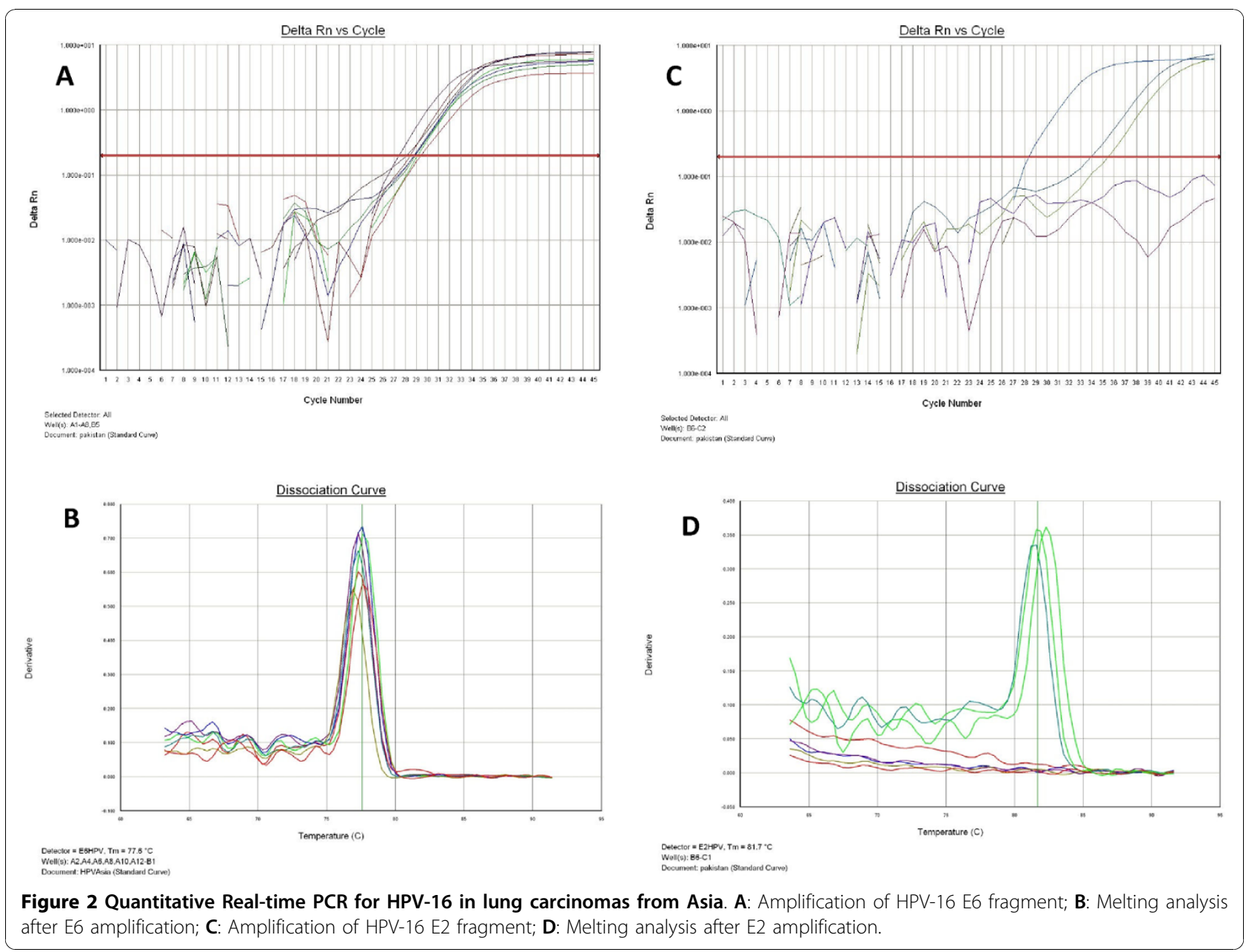

diseases in southern Taiwan, and is suspected to increase the risk of cancers of the lung, bladder and liver [22].

The variable frequencies of HPV-positive lung carcinomas between countries and continents may be explained by differences in sensitivity of the molecular methods used for HPV detection. PCR has been the most popular method used to detect HPV infection [3];

Table 3 Physical status of HPV-16 in lung carcinomas

\begin{tabular}{ccccl}
\hline Case & $\begin{array}{c}\text { E6 } \\
\text { Copies/100 } \mathbf{n g}\end{array}$ & $\begin{array}{c}\text { E2 } \\
\text { Copies/100 } \mathbf{~ n g}\end{array}$ & E2/E6 & Physical status \\
\hline 1 & 411 & 0 & 0 & Integrated \\
2 & 1737 & 35 & 0.02 & Mixed \\
3 & 2139 & 0 & 0 & Integrated \\
4 & 1724 & 0 & 0 & Integrated \\
5 & 1384 & 7.6 & 0.0055 & Mixed \\
6 & 1876 & 0 & 0 & Integrated \\
7 & 2345 & 0 & 0 & Integrated \\
8 & 42141 & 21071 & 0.5 & Mixed \\
\hline
\end{tabular}

however the different amplification protocols and primers used make it difficult to compare study results.

The present study found HPV-16 integration in cellular genome in every HPV-16 positive carcinoma. Even so, the low HPV load observed in the present study and in our previous study in Chile makes it difficult to interpret its etiological significance. It should be pointed out however that human cancer can be considered as a stem cell disease originated from a small fraction of cancer cells that show self-renewal and pluripotency and are capable of initiating and sustaining tumor growth [23]. HPV may be present only in a small fraction of cancer cells with stem cell like nature present even in advanced tumors. The transmission route of HPV detected in the upper aerodigestive tract cancers is yet unclear. One possible transmission route of HPV to the lung is through the bloodstream as suggested by a few studies [24]. However, it was pointed out that the possibility of bloodstream transmission appears to be low because of the exclusive intraepithelial cycle of life of HPV infection [25]. Moreover, a recent study which compared the 
second cancer risk of 335 women with invasive cervical cancer and their first degree relatives did not find any increase of lung cancer risk among cervical cancer patients [26]. Another possibility is a sexual transmission. However, considering the fact that Islamic countries have low incidence of cervical cancer [27], which is almost exclusively caused by HPV infection, such a route is unlikely to explain the presence of HPV in SQCs from Pakistan. Since the virus can infect oral mucosa and subsequently, larynx and bronchial tissue, that may be the main source of HPV detected in the lung.

This report has some methodological biases that need to be commented: First, DNA specimens from paraffin embedded tissues are known to be degraded because of heat during embedding and formalin fixation. Therefore, the present study might have underestimated the viral load "in vivo". Second, the amplification through PCR is not able to detect HPV directly in tumoral cells, so in the future a very sensitive "in situ" method to detect HPV or an alternative method to obtain only tumoral cells from clinical specimens, as tissue microdissection are warranted.

\section{Conclusion}

The results obtained in this study support the notion that HPV-16 infection is more strongly associated with SQCs than with ACs in the areas other than far-east Asian countries. Even though HPV-16 was frequently integrated in lung carcinomas, its low viral load casts doubt on a direct etiological role, which has been well established in the case of uterine cervical cancer. However, whether HPV-16 has a direct or indirect impact in the tumour development or modulation remains to be investigated.

\section{Methods}

\section{Study subjects}

We examined 60 bronchoscopic biopsy specimens of paraffin-embedded tissue of SQCs $(\mathrm{N}=30)$ and ACs $(\mathrm{N}=32)$ of the lung from Pakistan, China and Papua New Guinea (PNG). The cases from Pakistan $(\mathrm{N}=22)$ were diagnosed in Pathology Department of King Edward Medical University, Mayo Hospital, Lahore, Pakistan from 1996 to 2002. Cases from PNG were diagnosed in the period 1986-88 at Pathology Department of Port Moresby General Hospital, the major teaching center of School of Medicine \& Health Sciences, University of Papua New Guinea. Cases from China were diagnosed during the period between 1989 and 2002 in hospitals in eastern China. Based on 1982 WHO classifications of lung tumors, lung carcinomas were classified into four broad categories: SQCs, ACs, small cell carcinomas and large cell carcinomas [28]. In the present study, histological classification was made using the guideline of the Japan Lung Cancer Society [29], which follows the WHO classification. The institutional review board of the Kagoshima University Graduate School of Medical and Dental Sciences of Japan approved the present study.

\section{Polymerase chain reaction (PCR) and Southern blotting}

Ten- $\mu$ m-thick sections of each formalin-fixed paraffinembedded sample were prepared. The samples were added with $1 \mathrm{~mL}$ of xylene, and then with $1 \mathrm{~mL}$ of ethanol. After centrifugation, the pellet was resuspended in digestion buffer (50 mM Tris- $\mathrm{Cl} \mathrm{pH}$ 8.0, $1 \mathrm{mM}$ EDTA $\mathrm{pH}$ 8.0, 0.5\% Tween 20) containing $200 \mu \mathrm{g}$ of Proteinase $\mathrm{K}$ (Invitrogen Corp., USA) and incubated during 24 hours at $56^{\circ} \mathrm{C}$. The solution was heated at $100^{\circ} \mathrm{C}$ for $10 \mathrm{~min}$ and centrifuged at $10,000 \mathrm{rpm}$ for $10 \mathrm{~min}$. After phenol/Chloroform extraction, the obtained DNA was quantified using the Nanodrop 1000 spectrophotometer. HPV amplification with GP5+/GP6+ primers [30] was made in a reaction mixture that contained $2.5 \mu \mathrm{L}$ of sample (containing $100 \mathrm{ng}$ of DNA), $200 \mu \mathrm{M}$ dNTP, $0.5 \mu \mathrm{M}$ of each primer and 1.0 U Taq DNA polymerase (Takara, Japan) in a total volume of $25 \mu \mathrm{L}$ of reaction buffer ( $50 \mathrm{mM} \mathrm{KCl}, 20 \mathrm{mM}$ Tris-Cl, $\mathrm{pH} 8.3$ ). A "hot start" protocol was used with the following conditions of amplification: initial denaturation at $95^{\circ}$ for $4 \mathrm{~min}$; subsequent 45 cycles at $95^{\circ} \mathrm{C}$ for $1 \mathrm{~min}, 40^{\circ} \mathrm{C}$ for $2 \mathrm{~min}$ and $72^{\circ} \mathrm{C}$ for $1.5 \mathrm{~min}$ and final extension at $72^{\circ} \mathrm{C}$ for $5 \mathrm{~min}$. The amplification of a betaglobin fragment with a set of $\mathrm{PCO} 3 / \mathrm{PCO} 4$ primers (Takara, Japan) was used as internal positive control. All the analysed samples were betaglobin positive. The PCR program was as follows: initial denaturation at $95^{\circ} \mathrm{C}$ for $4 \mathrm{~min}, 40$ cycles with the cycling profile of $95^{\circ} \mathrm{C}$ for $1 \mathrm{~min}, 52^{\circ} \mathrm{C}$ for $1 \mathrm{~min}$ and $72^{\circ} \mathrm{C}$ for $2 \mathrm{~min}$ and final extension for $5 \mathrm{~min}$ at $72^{\circ} \mathrm{C}$. In addition, the generic HPV presence was detected using another L1 region as previously reported [31]. The specific HPV-16 amplification was made according to the following conditions: initial denaturation at $95^{\circ} \mathrm{C}$ for $5 \mathrm{~min}, 45$ cycles with the cycling profile of $94^{\circ} \mathrm{C}$ for $45 \mathrm{~s}, 55^{\circ} \mathrm{C}$ for $45 \mathrm{~s}$ and $72^{\circ} \mathrm{C}$ for $45 \mathrm{~s}$ and a final extension for $5 \mathrm{~min}$ at $72^{\circ} \mathrm{C}$. The amplified products were detected through electrophoresis on 3.0\% agarose gel.

\section{Quantitative Real-time PCR}

Real-time PCR was performed using the ABI Prism 7000 Sequence Detection System and SYBR-Green PCR master mix (PE, Applied Biosystems, USA). The amplification conditions were $10 \mathrm{~min}$ at $95^{\circ} \mathrm{C}$ and a two-step cycle of $95^{\circ} \mathrm{C}$ for $15 \mathrm{sec}$ and $60^{\circ} \mathrm{C}$ for $60 \mathrm{sec}$ for a total of 45 cycles. The primers used were: E6F: gagaaactgcaatgtttcaggacc and E6R: tgtatagttgtttgcagctctgtgc, 
E2F: aacgaagtatcctctcctgaaattattag and E2R: ccaaggcgacggctttg that amplify a fragment of 81 and $76 \mathrm{bp}$ of E6 and E2 ORFs, respectively [32]. The final concentration of the primers was $0.5 \mu \mathrm{M}$. Two standard curves for the E2 and E6 fragments were made by amplification of dilutions between $1 \times 10^{7}$ and $1 \times 10^{1}$ copies of HPV-16 cloned in pUC plasmid (kindly given by Dr. Massimo Tommasino, IARC, France). The specificity of amplification was confirmed using dissociation analysis starting at $60^{\circ} \mathrm{C}$ and agarose gel electrophoresis of the amplified products. In order to find out the physical status of HPV-16, the ratio of E2 to E6 copy numbers was calculated.

\section{Statistical analysis}

Fisher's exact test was used to examine the statistical significance of the results. A p-value $<0.05$ was considered statistically significant. P values presented are twosided.

\section{Acknowledgements}

This work was financed by Grants-in-Aid for Scientific Research on Priority areas (12218231 and 17015037) of the Ministry of Education, Culture, Sports, Science and Technology, Japan.

\section{Author details \\ ${ }^{1}$ Molecular Pathology and Epidemiology Laboratory, Public Health Department, Faculty of Medicine, P Universidad Catolica de Chile, Santiago, Chile. ${ }^{2}$ Department of Epidemiology and Preventive Medicine, Kagoshima University Graduate School of Medical and Dental Sciences, 8-35-1 Sakuragaoka, Kagoshima, 890-8544, Japan. ${ }^{3}$ Division of Individual Monitoring and Health Surveillance, National Institute for Radiological Protection, Chinese Center for Disease Control and Prevention, 2 Xinkang Street, Deshengmenwai, Xicheng District, Beijing 100088, China. ${ }^{4}$ School of Medicine and Health Sciences, University of Papua New Guinea. ${ }^{5}$ Division of Oncogenic and Persistent Viruses, Center for Chronic Viral Diseases, Kagoshima University Graduate School of Medical and Dental Sciences, 8-35- 1 Sakuragaoka, Kagoshima, 890-8544, Japan. ${ }^{6}$ Programa de Virología, Instituto de Ciencias Biomédicas (ICBM), Facultad de Medicina, Universidad de Chile, Santiago, Chile.}

\section{Authors' contributions}

FA, SA and CK conceived of the study, analysed the data and participated in the redaction of the manuscript. FA and $A C$ made all the analysis of the clinical specimens. MA, QS and JM gave clinical information and got specimens for analysis. YE and CK gave analytical support for all the analysis. All authors read and approved the final manuscript.

\section{Competing interests}

The authors declare that they have no competing interests.

Received: 25 August 2010 Accepted: 16 November 2010 Published: 16 November 2010

\section{References}

1. zur Hausen H: Papillomaviruses in the causation of human cancers - a brief historical account. Virology 2009, 384:260-265.

2. Trottier $\mathrm{H}$, Burchell AN: Epidemiology of mucosal human papillomavirus infection and associated diseases. Public Health Genomics 2009, 12:291-307.

3. Srinivasan M, Taioli E, Ragin CC: Human papillomavirus type 16 and 18 in primary lung cancers-a meta-analysis. Carcinogenesis 2009, 30:1722-1728.

4. Miyagi J, Tsuhako K, Kinjo T, Iwamasa T, Hirayasu T: Recent striking changes in histological differentiation and rate of human papillomavirus infection in squamous cell carcinoma of the lung in Okinawa, a subtropical island in southern Japan. J Clin Pathol 2000, 53:676-684.

5. Aguayo F, Castillo A, Koriyama C, Higashi M, Itoh T, Capetillo M, Shuyama K, Corvalan A, Eizuru Y, Akiba S: Human papillomavirus-16 is integrated in lung carcinomas: a study in Chile. Br J Cancer 2007, 97:85-91.

6. Yu Y, Yang A, Hu S, Yan H: Correlation of HPV-16/18 infection of human papillomavirus with lung squamous cell carcinomas in Western China. Oncol Rep 2009, 21:1627-1632.

7. Nadji SA, Mahmoodi M, Ziaee AA, Naghshvar F, Torabizadeh J, Yahyapour Y, Nategh R, Mokhtari-Azad T: An increased lung cancer risk associated with codon 72 polymorphism in the TP53 gene and human papillomavirus infection in Mazandaran province, Iran. Lung Cancer 2007, 56:145-151.

8. Coissard CJ, Besson G, Polette MC, Monteau M, Birembaut PL, Clavel CE: Prevalence of human papillomaviruses in lung carcinomas: a study of 218 cases. Mod Pathol 2005, 18:1606-1609.

9. Park MS, Chang YS, Shin JH, Kim DJ, Chung KY, Shin DH, Moon JW, Kang SM, Hahn CH, Kim YS, Chang J, Kim SK: The prevalence of human papillomavirus infection in Korean non-small cell lung cancer patients. Yonsei Med J 2007, 48:69-77.

10. Cheng YW, Chiou HL, Sheu GT, Hsieh LL, Chen JT, Chen CY, Su JM, Lee H: The association of human papillomavirus 16/18 infection with lung cancer among nonsmoking Taiwanese women. Cancer Res 2001, 61:2799-2803.

11. Baba M, Castillo A, Koriyama C, Yanagi M, Matsumoto H, Natsugoe $S$, Shuyama KY, Khan N, Higashi M, Itoh T, Eizuru Y, Aikou T, Akiba S: Human papillomavirus is frequently detected in gefitinib-responsive lung adenocarcinomas. Oncol Rep 2010, 23:1085-1092.

12. Pao W, Miller V, Zakowski M, Doherty J, Politi K, Sarkaria I, Singh B, Heelan R, Rusch V, Fulton L, Mardis E, Kupfer D, Wilson R, Kris M, Varmus H: EGF receptor gene mutations are common in lung cancers from "never smokers" and are associated with sensitivity of tumors to gefitinib and erlotinib. Proc Natl Acad Sci USA 2004, 101:13306-13311.

13. Arias-Pulido $H$, Peyton $C L$, Joste $N E$, Vargas $H$, Wheeler $C M$ : Human papillomavirus type 16 integration in cervical carcinoma in situ and in invasive cervical cancer. J Clin Microbiol 2006, 44:1755-1762.

14. Hopman AH, Theelen W, Hommelberg PP, Kamps MA, Herrington CS, Morrison LE, Speel EJ, Smedts F, Ramaekers FC: Genomic integration of oncogenic HPV and gain of the human telomerase gene TERC at $3 q 26$ are strongly associated events in the progression of uterine cervical dysplasia to invasive cancer. J Pathol 2006, 210:412-419.

15. Ghittoni R, Accardi R, Hasan U, Gheit T, Sylla B, Tommasino M: The biological properties of E6 and E7 oncoproteins from human papillomaviruses. Virus Genes 2010, 40:1-13.

16. Narisawa-Saito M, Yoshimatsu Y, Ohno S, Yugawa T, Egawa N, Fujita M, Hirohashi S, Kiyono T: An in vitro multistep carcinogenesis model for human cervical cancer. Cancer Res 2008, 68:5699-5705.

17. Li W, Thompson CH, Cossart YE, O'Brien CJ, Liu J, Scolyer RA, Carter JR, Dalrymple C, Rose BR: The site of infection and ethnicity of the patient influence the biological pathways to HPV-induced mucosal cancer. Mod Pathol 2004, 17:1031-1037.

18. Kleter B, van Doorn $L$, Schrauwen L, Molijn A, Sastrowijoto S, ter Schegget J, Lindeman J, ter Harmsel B, Burger M, Quint W: Development and clinical evaluation of a highly sensitive PCR-reverse hybridization line probe assay for detection and identification of anogenital human papillomavirus. J Clin Microbiol 1999, 37:2508-2517.

19. Le CH, Ko YC, Cheng LS, Lin YC, Lin HJ, Huang MS, Huang JJ, Kao EL, Wang $\mathrm{HZ}$ : The heterogeneity in risk factors of lung cancer and the difference of histologic distribution between genders in Taiwan. Cancer Causes Control 2001, 12:289-300.

20. Chen SC, Wong RH, Shiu LJ, Chiou MC, Lee H: Exposure to mosquito coil smoke may be a risk factor for lung cancer in Taiwan. J Epidemiol 2008, 18:19-25.

21. Kuo CY, Wong RH, Lin JY, Lai JC, Lee H: Accumulation of chromium and nickel metals in lung tumors from lung cancer patients in Taiwan. J Toxicol Environ Health A 2006, 69:1337-1344.

22. Chen CJ, Chuang YC, You SL, Lin TM, Wu HY: A retrospective study on malignant neoplasms of bladder, lung and liver in blackfoot disease endemic area in Taiwan. Br J Cancer 1986, 53:399-405.

23. Boman BM, Wicha MS: Cancer stem cells: a step toward the cure. J Clin Oncol 2008, 26:2795-2799. 
24. Tseng CJ, Pao CC, Lin JD, Soong YK, Hong JH, Hsueh S: Detection of human papillomavirus types 16 and 18 mRNA in peripheral blood of advanced cervical cancer patients and its association with prognosis. $J$ Clin Oncol 1999, 17:1391-1396.

25. Cheng YW, Chiou HL, Chen JT, Chou MC, Lin TS, Lai WW, Chen CY, Tsai YY, Lee H: Gender difference in human papillomarvirus infection for nonsmall cell lung cancer in Taiwan. Lung Cancer 2004, 46:165-170.

26. Weber W, De Sabata MS, Paredes RM, Rodriguez G, Santos C, Sabillon JU, Zwahlen M: Cancer in first degree relatives of Latin American women with cervical cancer. A pilot study. Anticancer Res 2005, 25:1219-1223.

27. Parkin DM WS, Ferlay J, Thomas DB, (Ed.): Cancer Incidence in Five Continents. Lyon: IARC Scientific publications No. 155; 2002.

28. WHO: The World Health Organization histological typing of lung tumours. Second edition. Am J Clin Pathol 1982, 77:123-136.

29. Society TJLc: Classification of lung cancer. 1 edition. Tokyo: Kanehara \& Co., Ltd.; 2000

30. de Roda Husman AM, Walboomers JM, van den Brule AJ, Meijer CJ, Snijders PJ: The use of general primers GP5 and GP6 elongated at their $3^{\prime}$ ends with adjacent highly conserved sequences improves human papillomavirus detection by PCR. J Gen Virol 1995, 76(Pt 4):1057-1062.

31. Shuyama K, Castillo A, Aguayo F, Sun Q, Khan N, Koriyama C, Akiba S: Human papillomavirus in high- and low-risk areas of oesophageal squamous cell carcinoma in China. Br J Cancer 2007, 96:1554-1559.

32. Peitsaro $P$, Johansson $B$, Syrjanen S: Integrated human papillomavirus type 16 is frequently found in cervical cancer precursors as demonstrated by a novel quantitative real-time PCR technique. J Clin Microbiol 2002, 40:886-891.

doi:10.1186/1750-9378-5-20

Cite this article as: Aguayo et al:: Human papillomavirus-16 presence and physical status in lung carcinomas from Asia. Infectious Agents and Cancer 2010 5:20

\section{Submit your next manuscript to BioMed Central and take full advantage of:}

- Convenient online submission

- Thorough peer review

- No space constraints or color figure charges

- Immediate publication on acceptance

- Inclusion in PubMed, CAS, Scopus and Google Scholar

- Research which is freely available for redistribution

Submit your manuscript at www.biomedcentral.com/submit 